\title{
Clinical and laboratory profile of Zika virus infection in dengue suspected patients: A case series
}

\author{
Cássia Fernanda Estofolete ${ }^{\mathrm{a}, 1}$, Ana Carolina Bernardes Terzian ${ }^{\mathrm{a}, 1}$, Ricardo Parreira ${ }^{\mathrm{b}}$, \\ Aida Esteves ${ }^{\mathrm{b}}$, Lucas Hardman ${ }^{\mathrm{a}}$, Gilmar Valdir Greque ${ }^{\mathrm{c}}$, Paula Rahal ${ }^{\mathrm{d}}$, \\ Maurício Lacerda Nogueira ${ }^{\mathrm{a}, *}$

\footnotetext{
a São José do Rio Preto School of Medicine (FAMERP), Avenida Brigadeiro Faria Lima, 5416. Vila São Pedro. São José do Rio Preto, CEP: 15090-000, SP, Brazil

b Global Health and Tropical Medicine (GHTM), Universidade Nova de Lisboa, Rua da Junqueira Nº 100, 1349-008 Lisboa, Portugal

c São José do Rio Preto Regional School of Medicine Foundation (FUNFARME), Avenida Brigadeiro Faria Lima, 5416. Vila São Pedro. São José do Rio Preto, SP, CEP: 15090-000, Brazil

${ }^{\mathrm{d}}$ Department of Biology, Institute of Biosciences, Letters, and Exact Sciences - São Paulo State University, São José do Rio Preto - (IBILCE/UNESP), Rua Cristóvão Colombo, 2265, CEP: 15054-000 - São José do Rio Preto, SP, Brazil
}

\section{A R T I C L E I N F O}

\section{Article history:}

Received 18 March 2016

Received in revised form 20 May 2016

Accepted 26 May 2016

\section{Keywords:}

Zika virus

Dengue virus

Chikungunya virus

NS1

Arbovirus

\begin{abstract}
A B S T R A C T
Background: The Zika virus (ZIKV) is an emerging arthropod-borne virus related to the dengue virus (DENV), and shows a similar clinical profile as other arboviral diseases, such as dengue and chikungunya virus (CHIKV). Historically, ZIKV has been associated with sporadic cases of human infection, but is now responsible for outbreaks worldwide. In Brazil, cases have been reported since 2015, with some cases causing severe disease.

Objective: To identify clinical symptoms of Zika in patients in Dengue suspected patients.

Study design: Description of a series of cases, wherein we analyzed 100 clinical samples collected from patients who exhibited acute febrile disease for $\leq 5$ days, from January to February 2016.

Results: In this study, we report 13 cases of ZIKV infection in adults presenting dengue-like symptoms in a DENV endemic area. All patients presented with fever, with myalgia being the second most frequently observed symptom. Two patients had rashes, but none of them had conjunctivitis. Other less frequent manifestations included headache, arthralgia, diarrhea, and nausea.

Conclusion: The co-circulation of ZIKV and DENV is a serious public health concern, since it represents both a clinical and diagnostic challenge in endemic areas, as well as in the field of travel medicine.
\end{abstract}

(c) 2016 Elsevier B.V. All rights reserved.

\section{Background}

The Zika virus (ZIKV) is a positive-sense, single-stranded RNA virus belonging to the genus Flavivirus within the family Flaviviridae. It is closely related to other flaviviruses with public health relevance, including the dengue (DENV), tick-borne encephalitis (TBEV), and West Nile viruses [1]. Although Aedes aegypti is consid-

\footnotetext{
* Corresponding author at: Avenida Brigadeiro Faria Lima, 5416. Vila São Pedro. São José do Rio Preto, SP, CEP: 15090-000, Brazil.

E-mail addresses: cassiafestofolete@gmail.com (C. Fernanda Estofolete), anacarolinaterzian@gmail.com (A.C.B. Terzian), ricardo@ihmt.unl.pt (R. Parreira), aidaesteves@ihmt.unl.pt (A. Esteves), lucashardman@hotmail.com

(L. Hardman), greque@terra.com.br (G.V. Greque), rahalp@yahoo.com.br (P. Rahal), mnogueira@famerp.br (M.L. Nogueira).

1 These authors contributed equally to this work.
}

ered the main vector outside of the African continent, A. albopictus has long been suspected to also be a vector [2].

Isolated for the first time in Uganda in 1947 [3], ZIKV was initially thought to cause sporadic benign human infections in Africa and Asia [4]. However, after the first documented outbreak of ZIKV outbreak on Yap Island, Micronesia, in 2007 [5], there was another large epidemic in French Polynesia in 2013-14, before it spread throughout the Pacific. ZIKV is now considered to be an emerging arthropod-borne virus [4,6]. The first evidence of the autochthonous transmission of ZIKV in Brazil was reported in the northeastern region of the country, in May 2015 [7]. Although ZIKV infection has been typically associated with a relatively mild illness, an increase in the newborn microcephaly cases from the northeastern Brazilian states has suggested an association between ZIKV infection during pregnancy and fetal malformations. The presence of this arbovirus has become an important public health concern [8], particularly because of the co-circulation of DENV, an endemic 
Table 1

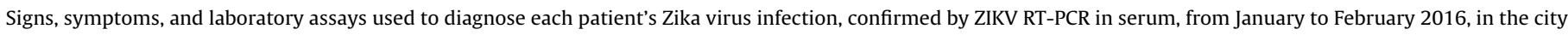
of São José do Rio Preto.

\begin{tabular}{|c|c|c|c|c|c|c|}
\hline Patient n (age) & Gender & Hospitalization & NS1 Antigen test & Dengue IgM & Dengue IgG & $\begin{array}{l}\text { Signs, Symptoms, and Selected } \\
\text { Laboratory Results }\end{array}$ \\
\hline 1 (76y) & Female & No & NP & Non reactive & Reactive & $\begin{array}{l}\text { Clinical: fever, myalgia, } \\
\text { headache, diarrhea Serum: Ht } \\
40,1 \% \text {; patelets } 110,000 / \mathrm{mm}^{3}\end{array}$ \\
\hline $2(34 y)$ & Female & No & Non reactive & NP & NP & $\begin{array}{l}\text { Clinical: fever, myalgia, } \\
\text { headache, retro-orbital pain. } \\
\text { Serum: Ht } 33.4 \% \text {; patelets } \\
156,000 / \mathrm{mm}^{3}\end{array}$ \\
\hline $3(23 y)$ & Female & No & Non reactive & NP & NP & $\begin{array}{l}\text { Clinical: fever, myalgia, } \\
\text { headache, retro-orbital pain, } \\
\text { arthralgia, mucosal bleeding. } \\
\text { Serum: Ht } 37.4 \% \text {; patelets } \\
208,000 / \mathrm{mm}^{3}\end{array}$ \\
\hline 4 (41y) & Male & No & Non reactive & NP & $\mathrm{NP}$ & $\begin{array}{l}\text { Clinical: fever, myalgia, } \\
\text { headache, chills, arthralgia, TT } \\
\text { negative. Serum: Ht } 40.4 \% \text {; } \\
\text { patelets } 211,000 / \mathrm{mm}^{3}\end{array}$ \\
\hline $5(25 y)$ & Male & No & NP & Non reactive & Non reactive & $\begin{array}{l}\text { Clinical: fever, myalgia, } \\
\text { diarrhea, nausea, Serum: Ht } \\
44.8 \% \text {; patelets } 201,000 / \mathrm{mm}^{3} \text {; } \\
\text { RCP } 0.95 \mathrm{mg} / \mathrm{dl} \text {; Cr: } 0.9 \mathrm{mg} / \mathrm{dl} \text {; } \\
\text { X-ray normal }\end{array}$ \\
\hline $6(43 y)$ & Female & No & Non reactive & NP & NP & $\begin{array}{l}\text { Clinical: fever, myalgia, nausea. } \\
\text { Serum: Ht 33.6\%; patelets } \\
307,000 / \mathrm{mm}^{3}\end{array}$ \\
\hline 7 (49y) & Female & No & Non reactive & NP & NP & $\begin{array}{l}\text { Clinical: fever, myalgia, } \\
\text { arthralgia, Serum: Ht } 42.8 \% \text {; } \\
\text { patelets } 145,000 / \mathrm{mm}^{3} ; \text { RCP: } \\
0.2 \mathrm{mg} / \mathrm{dl} ; \mathrm{Cr}: 1.0 \mathrm{mg} / \mathrm{dl} ; \text { AST } \\
32 \mathrm{UI} / \mathrm{l} ; \text { ALT } 60 \mathrm{UI} / \mathrm{l}\end{array}$ \\
\hline $8(38 y)$ & Male & No & Non reactive & NP & NP & $\begin{array}{l}\text { Clinical: fever, diarrhea. } \\
\text { Serum: Ht } 40.3 \% \text {; patelets } \\
\text { 143,000/mm³ } \text { RCP } 8.94 \mathrm{mg} / \mathrm{dl} \text {; } \\
\text { Cr: } 1.1 \mathrm{mg} / \mathrm{dl}\end{array}$ \\
\hline 9 (40y) & Female & No & Non reactive & Non reactive & Non reactive & $\begin{array}{l}\text { Clinical: fever, myalgia, } \\
\text { headache, retro-orbital pain, } \\
\text { exantema. TT positive. Serum: } \\
\text { Ht } 31.8 \% \text {; patelets } \\
224,000 / \mathrm{mm}^{3}\end{array}$ \\
\hline $10(67 y)$ & Male & No & Non reactive & NP & NP & $\begin{array}{l}\text { Clinical: fever, myalgia, } \\
\text { arthralgia, headache, } \\
\text { retro-orbital pain. TT negative. } \\
\text { Serum: Ht } 45.2 \% \text {; patelets } \\
175,000 / \mathrm{mm}^{3} \text {. Comorbidity: } \\
\text { Hypertension. }\end{array}$ \\
\hline 11 (65y) & Female & Yes & Non reactive & NP & $\mathrm{NP}$ & $\begin{array}{l}\text { Clinical: fever, headache, } \\
\text { mucosal bleeding, abdominal } \\
\text { pain. Serum: Ht } 40.8 \% \text {; patelets } \\
275,000 / \mathrm{mm}^{3} \text {; RCP } 4.35 \mathrm{mg} / \mathrm{dl} \text {; } \\
\mathrm{Cr} 0.8 \mathrm{mg} / \mathrm{dl} \text {; X ray normal; } \\
\text { Abdominal CT normal; } \\
\text { Comorbidity: Colon } \\
\text { diverticular disease. }\end{array}$ \\
\hline $12(19 y)$ & Female & No & Reactive & NP & NP & $\begin{array}{l}\text { Clinical: fever, myalgia, } \\
\text { arthralgia, headacheSerum: Ht } \\
44.6 \% \text {; patelets } 165,000 / \mathrm{mm}^{3}\end{array}$ \\
\hline $13(49 y)$ & Male & No & NP & Non reactive & Reactive & $\begin{array}{l}\text { Clinical: fever, myalgia, } \\
\text { exantema. Serum: Ht } 39.6 \% \text {; } \\
\text { patelets } 186,000 / \mathrm{mm}^{3}\end{array}$ \\
\hline
\end{tabular}

*NP: not performed; TT: tourniquet test; RCP: reactive C protein; Cr: creatinin; CT: computed tomography.

arbovirus in Brazil. Moreover, as previously revealed in clinical data from the French Polynesian outbreak, ZIKV has the potential to cause neurological complications such as meningoencephalitis and Guillain-Barré syndrome [9].

\section{Objectives}

In this study, we report the laboratory and clinical profiles of adults presenting dengue-like symptoms who came to our emer- gency health care facility from the city of São José do Rio Preto, located in the northwestern region of São Paulo State, Brazil. This region is considered endemic to the circulation of DENV and other arboviruses [10-12].

\section{Study design}

We analyzed 100 clinical samples from patients presenting with acute febrile disease for $\leq 5$ days from January to February 
2016. These patients were treated at the emergency facility of the reference hospital in São José do Rio Preto known as Hospital de Base. The illness was diagnosed as dengue based only on clinical-epidemiological data (clinical signs compatible with dengue and the local occurrence of an outbreak), as per the protocol from the Brazilian Ministry of Health (2009) [13]. Blood samples were collected and the patients were initially screened for DENV by NS1 and/or IgM-IgG (Alere S.A.), according to the attending physician request The sera was separated and the viral RNA extracted from $140 \mu \mathrm{L}$ of each serum sample using the QIAamp Viral RNA Mini kit (Qiagen), following the manufacturer's instructions. The RNA was analyzed by PCR/qPCR to detect DENV 1-4 [14], ZIKV [5] or CHIKV [15]. A conventional PCR was performed to test for ZIKV $[16,17]$. This study is part of an ongoing arbovirus surveillance program approved by the Ethical Review Board. All samples were in storage (at $-80^{\circ} \mathrm{C}$ ) when the study was initiated.

\section{Results}

Of the 100 patients analyzed, 13 were positive for the ZIKV genome as detected by PCR/qPCR. The DENV-1, DENV-2, and CHIKV genomes were detected in 26,13 , and 1 patients, respectively. No dengue, CHIKV, or Zika genomes were detected in the remaining 47 sera samples. Table 1 details the clinical and laboratory characteristics of the ZIKV positive patients in this study, while Table 2 compares these characteristics with those of patients from other Zika outbreaks worldwide [5,18-26]. The average age of the patients was 43.7 years \pm 17.39 years $(19-76$ years). $38 \%(n=5)$ of the patients were males. Further, $15 \%(n=2)$ of the patients had comorbidities such as colonic diverticular disease and hypertension. All of the patients had fever, with myalgia being the second most frequently observed symptom $(84.6 \%, n=11)$. The mean period between the onset of symptoms and administration of emergency care was 2.76 days ( \pm 1.42 , ranging between 1-6 days). The tourniquet test for dengue was performed on 3 patients, with only one testing positive. Two patients presented rashes; however, none of them had conjunctivitis. Other less frequent manifestations included headache, arthralgia, diarrhea, retro-ocular pain, and nausea. One patient was hospitalized because of abdominal pain and mucosal bleeding without thrombocytopenia. The NS1 antigen test was performed on 10 patients; however, only one was positive (despite PCR being negative for dengue). Furthermore, the DENV IgM detection test was performed on 4 patients, but none of them tested reactive. Two patients tested reagent for the DENV IgG test after turning symptomatic.

\section{Discussion}

ZIKV is an emerging arthropod-borne virus related to the DENV. Both viruses have similar epidemiology and transmission cycles in urban environments [27], and have spread across the Pacific Islands and in South America via long transmission chains. Their transmission involves vectors mainly from the Aedes genus, especially A. aegypti; however, there are anecdotal reports of human-to-human transmission events $[27,28]$.

ZIKV was rarely associated with human infection in the past. However, after a widespread epidemic in humans in 2007 [5], ZIKV is now considered an emerging arbovirus. Its emergence in Brazil occurred almost simultaneously as that of the chikungunya virus (CHIKV), also another arbovirus. In September 2014, the Brazilian Ministry of Health confirmed the autochthonous transmission of CHIKV in the states of Amapá and Bahia [29], and in May 2015, the autochthonous transmission of ZIKV was identified after a few patients presented with a "dengue-like syndrome" in the city of Natal, located in the state of Rio Grande do Norte [7].
ZIKV infection usually manifests with nonspecific clinical symptoms (mild fever, rash, arthralgia, and conjunctivitis); therefore, it can often be confused with other diseases. It is most commonly misdiagnosed as dengue or chikungunya [27], with the most commonly reported symptoms including fever, conjunctivitis, headache, myalgia, and pruritus. Less commonly reported symptoms include retro-orbital pain, anorexia, vomiting, diarrhea, and abdominal pain [30]. In this study, fever, myalgia, and headache were the most frequently reported symptoms, as these are the most common symptoms in Zika infection cases. It is noteworthy that conjunctivitis, often reported in ZIKV infection cases [30], was not observed in any of the patients in this study. Mild symptoms were observed in the majority of cases in this study; however, one ZIKV infected patient reported mucosal bleeding and abdominal pain, which are also dengue-warning signs. Because this patient had a previous colonic diverticular disease, these signs may be attributed to another condition, and not necessarily to the ZIKV infection. Laboratory test results showed hematocrit mean values of $39.6 \%( \pm 4.44 \%)$, and mean platelet count values of $187,384 /$ platelets $/ \mathrm{mm}^{3}\left( \pm 57.43 / \mathrm{mm}^{3}\right)$, which are similar to values from cases previously reported [31,32]. Thrombocytopenia (platelet counts $<100,000 / \mathrm{mm}^{3}$ ) [34-36] has also been commonly reported in previous dengue cases [33]. The results of the laboratory tests were therefore not sufficient to differentiate the cases distinctly. Information on the most common clinical signs and symptoms of the concurrent arboviruses circulating in the different areas of Brazil, along with an understanding of the associations between diseases and certain social, environmental, cultural, and economic factors, is crucial to implement an effective clinical and diagnostic management strategy, especially in cases of infections by emerging arthropod-borne viruses. Although the clinical behavior of DENV is known, ZIKV infection presents a new public health concern in this region, since can be easily misdiagnosed. Since the ZIKV infection is associated with morbidity, especially in pregnant women [8], deciphering the clinical and laboratory profiles of the ZIKV infection in an area with other arboviruses co-circulating and demonstrating that these symptoms differ from the previous outbreaks $[10,12]$ are pivotal for an early diagnosis of this infection as well as for reducing associated morbidity and mortality.

ZIKV infection has been typically associated with relatively mild illness. It can, however, be presented as severe disease, and with neurological complications such as Guillain-Barré syndrome, hearing difficulties [37] and more recently with microcephaly. The association between ZIKV infection during pregnancy and microcephaly in newborns was determined after an increase in microcephaly cases in newborns was observed in the northeastern region of Brazil, thus indicating a maternal-fetal virus transmission [8]. DENV and ZIKV co-infections [38], as well as DENV and CHIKV co-infections [39], making diagnosis and clinical management even more challenging, have already been reported. The outbreaks of these two major mosquito-borne infections in parallel to the endemic DENV infections pose a serious potential threat to the local and supra-national South American healthcare systems, an issue which has been recently observed in the Pacific Region [40]. Dengue is endemic in the city of São José do Rio Preto, with previously reported outbreaks [12]. Hence, there is information on the DENV behavior; however, ZIKV infection represents a new public health concern in this region, and continues to be misdiagnosed.

The diagnostic value of RT-PCR for the detection of ZIKV RNA in blood is limited, since ZIKV viremia is usually low and limited to the first 2-3 days after the onset of the disease. Higher ZIKV RNA loads are detectable in the urine after a longer period (10-20 days after the onset of symptoms), enabling the detection of the ZIKV RNA in urine to be a potential alternative diagnostic technique [41]. In this study, serum samples were collected after a mean period of 2.76 days following the onset of symptoms, which also represents 
Table 2

Reported or observed clinical and laboratory signs and symptoms in patients with Zika virus infection, 1962-2016.

Reported or observed clinical signs and symptoms in patients with Zika virus infection, 1962-2016

\begin{tabular}{|c|c|c|c|c|c|c|c|c|c|}
\hline & $\begin{array}{l}\text { Uganda, } 1962 \\
{[18], \mathrm{n}=1}\end{array}$ & $\begin{array}{l}\text { Laboratory, } \\
\text { acquired, } 1973 \\
\text { [19], } \mathrm{n}=1\end{array}$ & $\begin{array}{l}\text { Indonesia, } \\
\text { 1977-78 [20], } \\
\mathrm{n}=7\end{array}$ & $\begin{array}{l}\text { Micronesia, } \\
2007[5,21], \\
n=31\end{array}$ & $\begin{array}{l}\text { Senegal/USA,2009 } \\
{[22], \mathrm{n}=3}\end{array}$ & $\begin{array}{l}\text { Cambodia, } \\
2010 \text { [23], n=1 }\end{array}$ & $\begin{array}{l}\text { French } \\
\text { Polynesia, } \\
2013-14, \\
{[24,26], n=297}\end{array}$ & $\begin{array}{l}\text { Brazil (Bahia } \\
\text { State), } 2015 \\
{[25], n=7}\end{array}$ & $\begin{array}{l}\text { Brazil, São José } \\
\text { do Rio Preto, } \\
\text { São Paulo State, } \\
2016, n=13\end{array}$ \\
\hline Fever & $1(100 \%)$ & $1(100 \%)$ & $7(100 \%)$ & $20(65 \%)$ & NR & $1(100 \%)$ & $213(72 \%)$ & $6(85,7 \%)$ & $13(100 \%)$ \\
\hline Headache & $1(100 \%)$ & NR & NR & $14(45 \%)$ & $3(100 \%)$ & $1(100 \%)$ & $136(46 \%)$ & $3(43 \%)$ & $8(61.5 \%)$ \\
\hline Malaise & $1(100 \%)$ & NR & $5(71 \%)$ & NR & $3(100 \%)$ & NR & NR & NR & NR \\
\hline $\begin{array}{l}\text { Maculopapular } \\
\text { rash }\end{array}$ & $1(100 \%)$ & NR & NR & $28(90 \%)$ & $3(100 \%)$ & NR & $276(93 \%)$ & $6(85.7 \%)$ & $2(15.4 \%)$ \\
\hline $\begin{array}{l}\text { Fatigue or } \\
\text { myalgia }\end{array}$ & $1(100 \%)$ & $1(100 \%)$ & $1(14 \%)$ & $15(48 \%)$ & $1(33 \%)$ & NR & $231(78 \%)$ & $4(57.1 \%)$ & $11(84.6 \%)$ \\
\hline $\begin{array}{l}\text { Arthritis and } \\
\text { arthralgia }\end{array}$ & NR & NR & $1(14 \%)$ & $20(65 \%)$ & $3(100 \%)$ & NR & $193(65 \%)$ & NR & $5(38.5 \%)$ \\
\hline Chills & NR & $1(100 \%)$ & $2(29 \%)$ & NR & $2(67 \%)$ & NR & NR & NR & $1(7.7 \%)$ \\
\hline Dizziness & NR & NR & $5(71 \%)$ & NR & & NR & & NR & $2(15.4 \%)$ \\
\hline $\begin{array}{l}\text { Joint swelling or } \\
\text { edema }\end{array}$ & NR & NR & NR & $6(19 \%)$ & $2(67 \%)$ & NR & $139(46 \%)$ & NR & NR \\
\hline Stomachache & NR & NR & $6(86 \%)$ & NR & NR & NR & NR & NR & NR \\
\hline $\begin{array}{l}\text { Retro-orbital } \\
\text { pain }\end{array}$ & NR & $1(100 \%)$ & NR & $12(39 \%)$ & NR & NR & 47 (16\%) & NR & $3(23 \%)$ \\
\hline Conjunctivitis & NR & NR & $1(14 \%)$ & $17(55 \%)$ & $1(33 \%)$ & NR & 187 (63\%) & NR & NR \\
\hline Anorexia & NR & NR & $4(57 \%)$ & NR & NR & NR & NR & NR & NR \\
\hline Photophobia & NR & NR & NR & NR & $1(33 \%)$ & NR & NR & NR & NR \\
\hline Vomiting & NR & NR & $1(14 \%)$ & $3(10 \%)$ & NR & NR & NR & NR & NR \\
\hline Diarrhea & NR & NR & $3(43 \%)$ & NR & NR & NR & NR & NR & $4(30.7 \%)$ \\
\hline Constipation & NR & NR & $3(43 \%)$ & NR & NR & NR & NR & NR & NR \\
\hline Sore throat & NR & NR & NR & NR & NR & $1(100 \%)$ & $68(23 \%)$ & NR & NR \\
\hline Cough & NR & NR & NR & NR & NR & $1(100 \%)$ & NR & NR & NR \\
\hline Aphthous ulcer & NR & NR & NR & NR & $2(67 \%)$ & NR & $12(4 \%)$ & NR & NR \\
\hline Hypotension & NR & NR & $2(29 \%)$ & NR & NR & NR & NR & NR & NR \\
\hline Hematuria & NR & NR & $1(14 \%)$ & NR & NR & NR & NR & NR & NR \\
\hline Prostatitis & NR & NR & NR & NR & $1(33 \%)$ & NR & NR & NR & NR \\
\hline Hematospermia & NR & NR & NR & NR & $1(33 \%)$ & NR & NR & NR & NR \\
\hline Sweating & NR & $1(100 \%)$ & NR & NR & NR & NR & NR & NR & NR \\
\hline Lightheadedness & NR & NR & NR & NR & $1(33 \%)$ & NR & NR & NR & NR \\
\hline Abdominal pain & NR & NR & NR & NR & NR & NR & $83(28 \%)$ & NR & $1(7.7 \%)$ \\
\hline Mucosal bleeding & NR & NR & NR & NR & NR & NR & NR & NR & $2(15.4 \%)$ \\
\hline
\end{tabular}

NR: non reported.

a good timeframe for the detection of the ZIKV genome. The ZIKV genomic RNA encodes a polyprotein that is processed into three structural proteins and seven nonstructural proteins (NS), including the non-structural protein 1 (NS1) [42]. Similar to ZIKV, DENV NS1 is also associated with the intracellular membranes and the cell surface [43]. All flavivirus NS1 genes share a high degree of homology and encode a 46-55 kDa polypeptide, depending on their glycosylation status [44]. The NS1 lateral flow test is widely used in many developed and developing regions at risk for dengue [45]. The reported sensitivity of the NS1 antigen tests ranges from $48.5 \%$ to $58.6 \%$, and the specificity ranges from $92.5 \%$ to $99.4 \%$. The combined sensitivity of the dengue NS1 antigen and immunoglobulin M (IgM) antibody tests increases to $89.9-92.9 \%$, with a specificity of $75.0-88.8 \%$ [46]. False positive and misleading dengue virus NS1 antigen results have been previously described in patients with febrile illness and hematological malignancies [45,47]. In the current study, 10 patients, who tested positive for Zika and negative for dengue based on PCR, had the NS1 test performed after hospitalization. The test result was reagent in one case, showing cross-reactivity between dengue and Zika.

Serological cross-reactivity between ZIKV and DENV has been observed in earlier studies $[5,48]$. This cross-reactivity leads to the misdiagnosis of dengue because of the similarity of the clinical symptoms in addition to serological cross-reactivity. Using serological tests, Lanciotti et al., [5] showed that ZIKV-infected patients can test positive in the IgM assay for DENV, particularly if ZIKV is the cause of a secondary flavivirus infection. The authors also reported that, if ZIKV was the first flavivirus encountered, then cross-reactivity was minimal; however, if the ZIKV infection occurred after a flavivirus infection, the extent of cross-reactivity in the IgM assay was higher. Therefore, if ZIKV infections occurred in a population with DENV (or other flaviviruses) background immunity, extensive cross-reactivity in the dengue IgM assay would be seen. This could, therefore, potentially lead to the erroneous conclusion that dengue was the cause of the outbreak. In this study, dengue IgM test was negative in patients with ZIKV infections. However, dengue IgG detection test was performed in 4 patients, the results being positive in 2 of them. ZIKV was introduced after DENV and CHIKV in the city of São José do Rio Preto, and immunization against yellow fever is common, with a vaccination coverage of 96\% [49]. Therefore, ZIKV represents a secondary flavivirus infection in a population that exhibits cross-reactivity in DENV IgG assay.

ZIKV infection is of great concern to public health, since it represents both a clinical and diagnostic challenge in both endemic areas and in the field of travel medicine. Many factors contribute to issues in the clinical assessment and delays in initiating the appropriate management for individual patients: the adaptation of Zika virus to an urban or peri-urban cycle (involving Aedes spp. as vectors, and humans as amplification hosts), the fact that more than half of the world's population lives in areas infested with the mosquitoes, the spread of the disease via high population mobility, a widespread occurrence of the vectors, similar clinical profiles of infections 
by the different (emerging) mosquito-borne viruses, false-positive results from diagnostic tests, and the complex epidemiological situation due to the co-circulation of the dengue, chikungunya, and Zika viruses. Hence, there is an urgent and imperative need for further studies and public initiatives.

\section{Competing interests}

None.

\section{Funding}

This work was supported by the São Paulo State Research Foundation (FAPESP) under Grant \# 2013/21719-3 to MLN and the 2015/12295-0 fellowship to ACBT. The FAPESP Zika Network supported this work. MLN is a CNPq fellow.

\section{Ethical approval}

This study is part of an ongoing arbovirus surveillance program approved by the Ethical Review Board of the São José do Rio Preto School of Medicine (FAMERP) Process \# 48982/2012.

\section{References}

[1] T.C.D.M. Pierson, Flaviviruses, in: D.M. Knipe PH (Ed.), Fields Virology, 6th ed. Philadelphia: Lippincott Williams \& Wilkins, 2013

[2] P.S. Wong, M.Z. Li, C.S. Chong, L.C. Ng, C.H. Tan, Aedes (Stegomyia) albopictus (Skuse): a potential vector of Zika virus in Singapore, PLoS Negl. Trop. Dis. 7 (8) (2013) e2348.

[3] G.W. Dick, S.F. Kitchen, A.J. Haddow, Zika virus: I. Isolations and serological specificity, Trans. R. Soc. Trop. Med. Hyg. 46 (5) (1952) 509-520.

[4] V.M. Cao-Lormeau, D. Musso, Emerging arboviruses in the Pacific, Lancet 384 (9954) (2014) 1571-1572

[5] R.S. Lanciotti, O.L. Kosoy, J.J. Laven, J.O. Velez, A.J. Lambert, A.J. Johnson, et al., Genetic and serologic properties of Zika virus associated with an epidemic, Yap State, Micronesia, 2007, Emerg. Infect. Dis. 14 (8) (2008) 1232-1239.

[6] E.B. Hayes, Zika virus outside africa, Emerg. Infect. Dis. 15 (9) (2009) $1347-1350$

[7] C. Zanluca, V.C. Melo, A.L. Mosimann, G.I. Santos, C.N. Santos, K. Luz, First report of autochthonous transmission of Zika virus in Brazil, Mem. Inst. Oswaldo Cruz 110 (4) (2015) 569-572.

[8] Control ECfDPa, Rapid Risk Assessment: Zika Virus Epidemic in the Americas Potential Association with Microcephaly and Guillain-Barré Syndrome. Stockholm2015 [cited 2016], 2016 (Available from) http://ecdc.europa.eu/en publications/Publications/zika-virus- americas-association-withmicrocephaly- rapid-risk-assessment.pdf.

[9] E. Oehler, L. Watrin, P. Larre, I. Leparc-Goffart, S. Lastere, F. Valour, et al. Zika virus infection complicated by Guillain-Barre syndrome-case report, French Polynesia, December 2013. Euro surveillance: bulletin Europeen sur les maladies transmissibles = European communicable disease bulletin, 19(9) (2014).

[10] A. Mondini, R.V. Bronzoni, I.L. Cardeal, T.M. dos Santos, E. Lazaro, S.H. Nunes, et al., Simultaneous infection by DENV-3 and SLEV in Brazil, J. Clin. Virol. 40 (1) (2007) 84-86.

[11] A. Mondini, I.L. Cardeal, E. Lazaro, S.H. Nunes, C.C. Moreira, P. Rahal, et al., Saint Louis encephalitis virus, Brazil, Emerg. Infect. Dis. 13 (1) (2007) 176-178.

[12] A.C. Terzian, A. Mondini, R.V. Bronzoni, B.P. Drumond, B.P. Ferro, E.M. Cabrera, et al., Detection of Saint Louis encephalitis virus in dengue-suspected cases during a dengue 3 outbreak, Vector Borne Zoonotic Dis. 11 (3) (2011) 291-300.

[13] Health BMo, Dengue No Brasil Informe Epidemiológico 12/2009 [cited 2009], 2009 (Available from) http://portalsaudegovbr/portal/arquivos/pdf/inform_ dengue_1905200922pdf2009.

[14] R.V. de Morais Bronzoni, F.G. Baleotti, R.M. Ribeiro Nogueira, M. Nunes, L.T Moraes Figueiredo, Duplex reverse transcription-PCR followed by nested PCR assays for detection and identification of Brazilian alphaviruses and flaviviruses, J. Clin. Microbiol. 43 (2) (2005) 696-702.

[15] R.S. Lanciotti, O.L. Kosoy, J.J. Laven, A.J. Panella, J.O. Velez, A.J. Lambert, et al., Chikungunya virus in US travelers returning from India, 2006, Emerg. Infect. Dis. 13 (5) (2007) 764-767.

[16] K. Katoh, H. Toh, Recent developments in the MAFFT multiple sequence alignment program, Brief. Bioinform. 9 (4) (2008) 286-298.

[17] A. Vazquez, M.P. Sanchez-Seco, G. Palacios, F. Molero, N. Reyes, S. Ruiz, et al., Novel flaviviruses detected in different species of mosquitoes in Spain, Vector Borne Zoonotic Dis. 12 (3) (2012) 223-229.

[18] D.I. Simpson, Zika virus infection in man, Trans. R. Soc. Trop. Med. Hyg. 58 (1964) 335-338.
[19] A.R. Filipe, C.M. Martins, H. Rocha, Laboratory infection with Zika virus after vaccination against yellow fever, Arch. Gesamte Virusforsch. 43 (4) (1973) 315-319.

[20] J.G. Olson, T.G. Ksiazek, Suhandiman, Triwibowo, Zika virus, a cause of fever in Central Java, Indonesia, Trans. R. Soc. Trop. Med. Hyg. 75 (3) (1981) 389-393.

[21] M.R. Duffy, T.H. Chen, W.T. Hancock, A.M. Powers, J.L. Kool, R.S. Lanciotti, et al., Zika virus outbreak on yap island, federated states of Micronesia, N. Engl. J. Med. 360 (24) (2009) 2536-2543.

[22] B.D. Foy, K.C. Kobylinski, J.L. Chilson Foy, B.J. Blitvich, A. Travassos da Rosa, A.D. Haddow, et al., Probable non-vector-borne transmission of Zika virus, Colorado, USA, Emerg. Infect. Dis. 17 (5) (2011) 880-882.

[23] V. Heang, C.Y. Yasuda, L. Sovann, A.D. Haddow, A.P. Travassos da Rosa, R.B. Tesh, et al., Zika virus infection, Cambodia, 2010, Emerg. Infect. Dis. 18 (2) (2012) 349-351.

[24] H. Mallet, Emergence du virus Zika en Polynésie Française, in: 15ème Journées Nationales dínfectologie, Bordeaus-France, 2014, pp. 28.

[25] G.S. Campos, A.C. Bandeira, S.I. Sardi, Zika virus outbreak, Bahia, Brazil, Emerg. Infect. Dis. 21 (10) (2015) 1885-1886.

[26] T.X.M.D. Nhan, Émergence du virus zika, Virologie 19 (5) (2015) 11.

[27] D. Musso, V.M. Cao-Lormeau, D.J. Gubler, Zika virus: following the path of dengue and chikungunya? Lancet 386 (9990) (2015) 243-244.

[28] O. Faye, C.C. Freire, A. Iamarino, O. Faye, J.V. de Oliveira, M. Diallo, et al., Molecular evolution of Zika virus during its emergence in the 20(th) century, PLoS Negl. Trop. Dis. 8 (1) (2014) e2636.

[29] M.R. Nunes, N.R. Faria, J.M. de Vasconcelos, N. Golding, M.U. Kraemer, L.F. de Oliveira, et al., Emergence and potential for spread of Chikungunya virus in Brazil, BMC Med. 13 (2015) 102.

[30] J. Heukelbach, C.H. Alencar, A.A. Kelvin, W.K. De Oliveira, L. Pamplona de Goes Cavalcanti, Zika virus outbreak in Brazil, J. Inf. Dev. Countries 10 (2) (2016) $116-120$.

[31] J.C. Kwong, J.D. Druce, K. Leder, Zika virus infection acquired during brief travel to Indonesia, Am. J. Trop. Med. Hyg. 89 (3) (2013) 516-517.

[32] L. Zammarchi, G. Stella, A. Mantella, D. Bartolozzi, D. Tappe, S. Gunther, et al., Zika virus infections imported to Italy: clinical, immunological and virological findings, and public health implications, J. Clin. Virol. 63 (2015) 32-35.

[33] DJ. Gubler, Dengue and dengue haemorrhagic fever, Malaysia. Releve epidemiologique hebdomadaire/Section d'hygiene du Secretariat de la Societe des Nations = Weekly epidemiological record/Health Section of the Secretariat of the League of Nations, 73(24) (1998) 182-3.

[34] M. Banerjee, C.T. Choudhary, G.S. Srinivas, V. Kataria, V.K. Dengue, a clinicohematologial profile, MJAF 64 (4) (2008) 4.

[35] I. Arshad, M.F. Hussain, A. Shahida, Dengue fever clinico-pathologic correlatiions and their association with poor outcome, Prof. Med. J. 18 (1) (2011) 7

[36] A.B. Bashir, B.A. Mohammed, O.K. Saeed, A.K. Ageep, Thrombocytopenia and bleeding manifestations among patients with dengue virus infection in Port Sudan, Red Sea State of Sudan, J. Infect. Dis. Immun. 7 (2) (2015) 7.

[37] D. Tappe, S. Nachtigall, A. Kapaun, P. Schnitzler, S. Gunther, J. Schmidt-Chanasit, Acute Zika virus infection after travel to Malaysian Borneo, September 2014, Emerg. Infect. Dis. 21 (5) (2015) 911-913.

[38] M. Dupont-Rouzeyrol, O. O'Connor, E. Calvez, M. Daures, M. John, J.P. Grangeon, et al., Co-infection with Zika and dengue viruses in 2 patients, New Caledonia, 2014, Emerg. Infect. Dis. 21 (2) (2015) 381-382.

[39] M. Caron, C. Paupy, G. Grard, P. Becquart, I. Mombo, B.B. Nso, et al., Recent introduction and rapid dissemination of Chikungunya virus and Dengue virus serotype 2 associated with human and mosquito coinfections in Gabon, central Africa, Clin. Infect. Dis. 55 (6) (2012) e45-53.

[40] A. Roth, A. Mercier, C. Lepers, D. Hoy, S. Duituturaga, E. Benyon, et al., Concurrent outbreaks of dengue, chikungunya and Zika virus infections - an unprecedented epidemic wave of mosquito-borne viruses in the Pacific 2012-2014. Euro surveillance: bulletin Europeen sur les maladies transmissibles = European communicable disease bulletin 19(41) (2014).

[41] A.C. Gourinat, O. O'Connor, E. Calvez, C. Goarant, M. Dupont-Rouzeyrol, Detection of Zika virus in urine, Emerg. Infect. Dis. 21 (1) (2015) 84-86.

[42] G. Kuno, G.J. Chang, K.R. Tsuchiya, N. Karabatsos, C.B. Cropp, Phylogeny of the genus Flavivirus, J. Virol. 72 (1) (1998) 73-83.

[43] I. Gutsche, F. Coulibaly, J.E. Voss, J. Salmon, J. d'Alayer, M. Ermonval, et al., Secreted dengue virus nonstructural protein NS1 is an atypical barrel-shaped high-density lipoprotein, Proc. Natl. Acad. Sci. U. S. A. 108 (19) (2011) 8003-8008.

[44] D.A. Muller, P.R. Young, The flavivirus NS1 protein: molecular and structural biology, immunology, role in pathogenesis and application as a diagnostic biomarker, Antiviral Res. 98 (2) (2013) 192-208.

[45] S.J. Chung, P.U. Krishnan, Y.S. Leo, Two cases of false-positive dengue non-structural protein 1 (NS1) antigen in patients with hematological malignancies and a review of the literature on the use of NS1 for the detection of Dengue infection, Am. J. Tropi. Med. Hyg. 92 (2) (2015) 367-369.

[46] S.D. Blacksell, R.G. Jarman, M.S. Bailey, A. Tanganuchitcharnchai, K. Jenjaroen, R.V. Gibbons, et al., Evaluation of six commercial point-of-care tests for diagnosis of acute dengue infections: the need for combining NS1 antigen and IgM/IgG antibody detection to achieve acceptable levels of accuracy, Clin. Vaccine Immunol. CVI 18 (12) (2011) 2095-2101.

[47] E.A. Hunsperger, S. Yoksan, P. Buchy, V.C. Nguyen, S.D. Sekaran, D.A. Enria, et al., Evaluation of commercially available diagnostic tests for the detection of dengue virus NS1 antigen and anti-dengue virus IgM antibody, PLoS Negl. Trop. Dis. 8 (10) (2014) e3171. 
[48] D. Gyurech, J. Schilling, J. Schmidt-Chanasit, P. Cassinotti, F. Kaeppeli, M.

Dobec, False positive dengue NS1 antigen test in a traveller with an acute Zika virus infection imported into Switzerland, Swiss Med. Wkly. 146 (2016) w14296.
[49] Painel de Monitoramento, Indicadores de 2014. São José do Rio Preto: Secretaria Municipal de Saúde. Gerência de Informações de Vigilância Sanitária, 2015, p. 32. 